\title{
Clarifying some assumptions of coastal management: Analysis of values and uncertainties embedded in beach quality indexes
}

\author{
Briana Bombana ${ }^{\mathrm{a}, \mathrm{b}}, *$, Eduard Ariza ${ }^{\mathrm{a}}$ \\ ${ }^{a}$ Universitat Autònoma de Barcelona, Departament de Geografia, Facultat de Filosofia i Lletres, Carrer de la Fortuna s/n, 08193 Cerdanyola del Vallès, Spain \\ ${ }^{\mathrm{b}}$ CAPES, Ministério da Educação do Brasil, SBN, Quadra 2, Lote 06, Bloco L, 70040-020 Brasília, DF, Brazil
}

\section{A R T I C L E I N F O}

\section{Keywords:}

Coastal management

Beach indexes

Knowledge assessment

Scientific assumptions

Uncertainties

Complexity

\begin{abstract}
A B S T R A C T
For the first time, this research addresses the assessment of the quality of knowledge embedded in beach quality indexes from a socioecological perspective. We took the most widespread beach quality indexes and identified, selected and assessed the most important existing assumptions. We scored the robustness of these assumptions, using an inclusive methodology (stakeholder meeting, four focus groups and an online questionnaire). The NUSAP criteria for assessing the value-ladenness of scientific studies (Influence of resource limitations, (Im)Plausibility, Choice space, Agreement among peers, Analysts' subjectivity and Influence on global results) were contrasted and discussed. A final list of the 10 weakest assumptions was presented and discussed. Most of these assumptions are fairly robust, but attention should mainly focus on their influence on global outcomes and (im)plausibility, as the weakest scored criteria. The choice space scores revealed the possibility of including new alternatives to the assumptions, when necessary. Assumptions loaded with framing concepts are weaker than those linked to more concrete objectives. We detected dissociation between the discourse and the operational development of the indexes, in which the narratives prioritizing user satisfaction are predominant and scientific data analysis is often decontextualized. We therefore suggest that science should be opened up throughout the building process of indexes: from the identification of problems to the reporting of results and related uncertainties. The NUSAP method proved to be useful for identifying weak points in beach quality indexes.
\end{abstract}

\section{Introduction}

The analysis of beaches as socioecological systems (SES) (e.g. Defeo and McLachlan, 2005, Botero and Hurtado, 2009) has been developed only in recent years, following almost three decades of use of analysis and ranking tools, that, despite contributing to this body of knowledge, failed to truly address the existing complexity of these systems (Ariza et al., 2008). Although traditionally claimed to be an objective process, the choice of which components and interactions are needed to understand the behaviour of SES is biased by scientists' values, interests and background (Rosen, 1993, Sarewitz, 2004, Bremer and Glavovic, 2013). Doing science for policy involves a number of renounces. In this way, approaches to the management of beach SES have traditionally focused on a very limited number of functions, such as beaches as summer playgrounds and buffer spaces for storms (James, 2000, Lozoya et al., 2014, Ariza et al., 2016). The process has prioritized specific narratives over others, resulting in a lack of scrutiny of the overall functioning of the system.

The assessment presented here takes and explores the potential contribution of the Post Normal Science (PNS) - a guiding epistemological perspective that emphasizes the high stakes and uncertainties involved in socioecological problems and alternatives (Funtowicz and Ravetz, 1990) - to beach management, by highlighting the enclosed narratives and contexts. In practical terms, we critically assessed the knowledge embedded in the existing beach quality indexes. We started the analysis with the BQI (see Section 2) and expanded it to 5 other well-known beach quality indexes, through the identification, screening and evaluation of their scientific assumptions. In order to do this, we applied one of the operational PNS tools: the NUSAP method.

\footnotetext{
* Corresponding author at: Universitat Autònoma de Barcelona, Departament de Geografia, Facultat de Filosofia i Lletres, Carrer de la Fortuna s/n, 08193 Cerdanyola del Vallès, Spain. Email address: briana.bombana@e-campus.uab.cat (B. Bombana)
} 


\section{Background of beach quality indexes and the epistemological framework}

\subsection{The evolution of beach management tools}

A consolidated line of research on beaches has led to the development of management practices and tools. In the first book dedicated to the topic, beach management is defined as a "subset of coastal management but with particular reference to pragmatic local management" (Williams and Micallef, 2009). Here, awards, rating schemes and sets of indicators to measure beach performance have been identified since 1985, when the Blue Flag rating scheme was developed as a response from the tourism industry to the crisis of mass tourism and its subsequent impacts on natural resources (Fraguell et al., 2013).

After the Blue Flag rating scheme, different initiatives began to appear in different countries (e.g. Leatherman, 1997, Morgan, 1999), designed to support costal leisure activity on beaches, accounting, in a very limited way, for environmental aspects (Williams and Micallef, 2009). Most importantly, they represented beaches as a static photograph rather than a dynamic system, since their usual methodology consisted of fulfilling a list of requirements for beach performance (e.g. Mir-Gual et al., 2015) ranking "where the 'best beaches' occur" (Williams and Micallef, 2009), most of them regardless of socioecological specificities and interactions.

In the late 1990s, the latest advances in sustainability research proposing more systemic approaches, i.e. Environmental Management Systems (EMS) (Seiffert, 2009), started to converge with the research on beach management (Yepes et al., 1999). This led to a more integrative process through the inclusion of different stakeholders in the analysis and decision-making, as is the case of the Spanish UNE-EN ISO 14.001 standard (Williams and Micallef, 2009). Nonetheless, quality standards were limited in their coverage of socioecological beach sys- tems due to their vocation towards market competitiveness in the tourism sector (Yepes, 2005).

The new century brought a turning point, when beaches were expressly defined as socioecological systems and the ecosystem-based management approach was included in the conceptual framework of the field (Ariza et al., 2008). Since then, scientists have proposed that natural beach assets should be better incorporated into classical certification schemes (Fraguell et al., 2016, Lucrezi et al., 2015) and especially new methodologies for capturing beach complexity in order to provide information for sustainable management (Ariza et al., 2010, Botero et al., 2015, Cervantes and Espejel, 2008, Semeoshenkova et al., 2015, Todd and Bowa, 2016, Lucrezi et al., 2016).

The Beach Quality Index (BQI; Ariza et al., 2010, 2012) was the first index designed to cater for different beach systems and functions in an integrated framework (Williams and Micallef, 2009). Hierarchically organized in four levels (Fig. 1), the first corresponds to the overall tool, the second to the three beach functions identified (natural, protective and recreational), followed by a third level composed of 13 sub-indexes, which finally deploy the corresponding measurement variables (fourth level).

\subsection{The uncertainty assessment}

The methodologies developed to date for capturing beaches as multidimensional systems (more in Table 1) have included non-academic narratives in a limited way, i.e. only beach users' perceptions. They did not consider uncertainty multidimensional assessment during the index building process (Walker et al., 2003), and did not include checks of their usefulness as a guide for political decisions on beach matters.

The PNS, more than an epistemological guide, seeks to bring the uncertainties of contemporary complex problems to the centre of academic studies (Funtowicz and Ravetz, 1990). It offers an alternative for analysing and diagnosing uncertainties: the NUSAP method (Fig. 2).

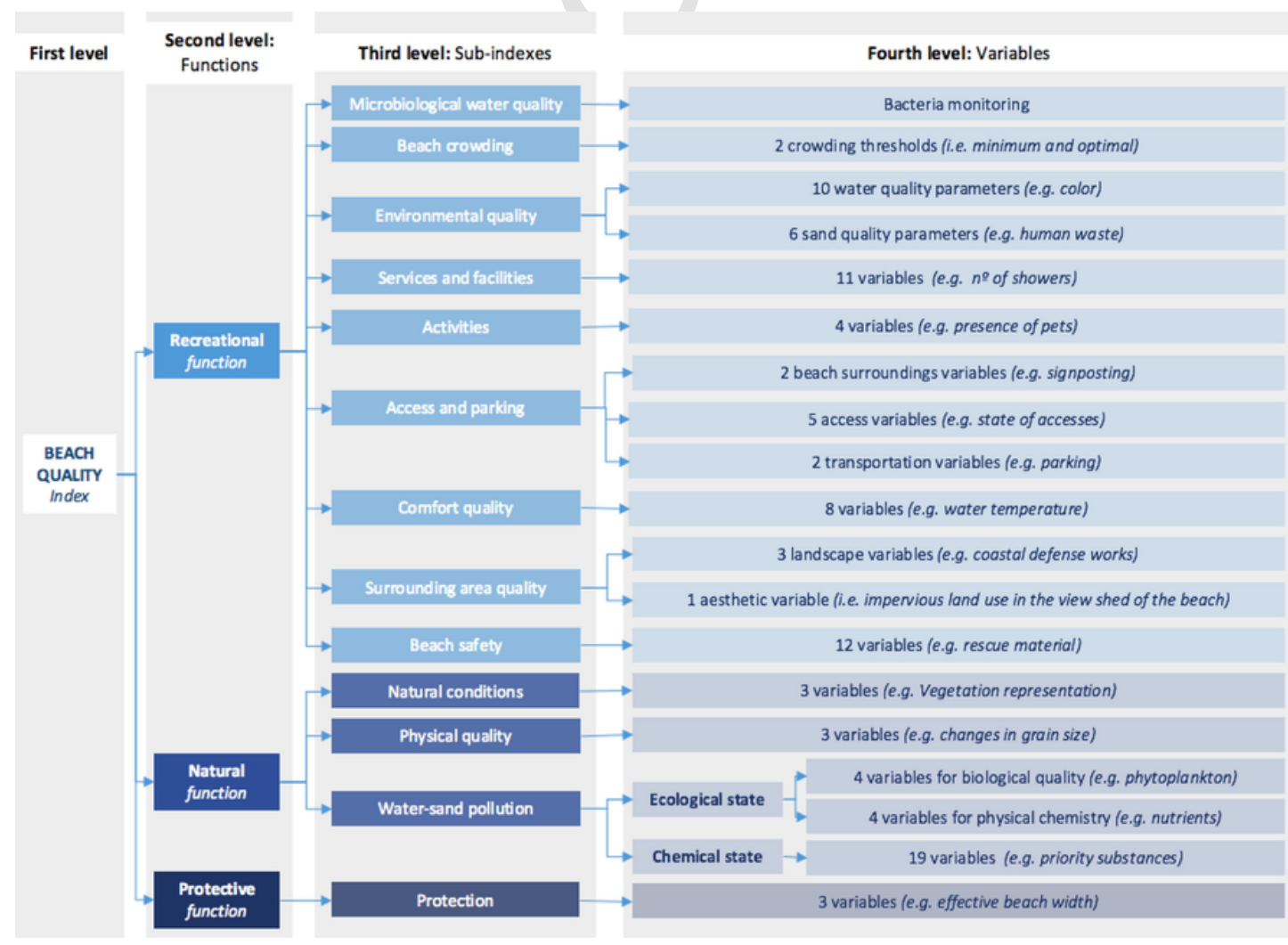

Fig. 1. The structural organization of the BQI components. Adapted from the BQI (Ariza et al., 2010). 
Table 1

Reference, main objective and design of the beach indexes.

\begin{tabular}{ll}
\hline Index & Authors \\
\hline Beach Quality & Ariza et al. \\
Index (BQI) & $(2010,2012)$
\end{tabular}

Integrated Beach Evaluation Index (IBVI)

\section{Cervantes and} Espejel (2008)

\begin{abstract}
Index of
Environmental

Quality in Tourist

Beaches (ICAPTU,

Spanish acronym)

Semeoshenkova et
\end{abstract}

al. Index

Beach Health Index

(BHI)

Beach Evaluation

Index (BEI)
Botero et al. (2015)

Semeoshenkova et al. (2015)

Todd and Bowa (2016)

Lucrezi et al. (2016)
Main objective and Index

design

Assesses the quality of urban and semi urban beaches, which weights and enables a comparison between three sets of sub-indexes. Each of these corresponds to one of the three beach functions: recreational, protective and natural. In addition, economic valuations were carried out.

Evaluates the quality of recreational sandy urban beaches through the weighting of a set of sub-indexes, divided into recreational capacity, opinion and attitude of users, and monetary sub-indexes. Assesses beach environmental quality by means of the ecosystem, sanitary and recreational quality of beaches.

Assesses the quality of beaches by analyzing environmental quality, human welfare and wealth.

Analyzes the health of oceanic beaches, by studying the functions of beaches emphasized by the BQI. Evaluates sandy beaches through a set of indicators: beach description (recreation and management), human dimension (attitude and opinion of beach users) and monetary calculations.

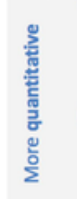

U Unity (e.g. the conventional sort, which may also contain extra information)

S Spread (i.e. usually the "random error", the "variance")

A Assessment (i.e. expert judgement of reliability)

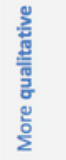

P Pedigree (i.e. systematic multi-criteria evaluation of the mode of production of the information)

Fig. 2. The dimensions of uncertainty, assessed by the NUSAP method. Adapted from Funtowicz and Ravetz (1990) and Van der Sluijs et al. (2003).

NUSAP is an acronym for Numeral and Unity (traditional statistical approach), extended to the dimensions of Spread (uncertainty and inexactness), Assessment of reliability (methodological) and Pedigree (quality of the production process, epistemological frameworks), in such a way that the value-ladenness of academic assessments can be highlighted (Van der Sluijs et al., 2003).
The NUSAP can be deployed by a pedigree assessment matrix, which may take different forms (e.g. Van der Sluijs et al., 2003, Kloprogge et al., 2011, Laes et al., 2011) through a set of pedigree criteria, such as analyst's objectivity and (dis)agreement among peers about the knowledge base. That used in Van der Sluijs and Wardekker (2015) has been adapted for this work (further details below) and represents a quali-quantitative structural process for assessing the assumptions, numbers and theories behind the available knowledge.

When Mayumi and Giampietro (2006) discussed the four sources of uncertainties presented by Knight (1964) - perception, anticipation, effect and implementation - they selected the first one as crucial for the PNS. The perception and further representation of our surrounding 'reality' is constrained by certain limitations, according to which, facts should be addressed taking into account the means used to put a shared question into perspective. In this regard, the treatment of the strength property is the most innovative part of the NUSAP method, since it is a way of reacting to the perception uncertainty, especially due to the focus on evaluating the process of information production (Ravetz and Funtowicz, n.d.). To date, the NUSAP method has not been used for the analysis of beach SES narratives and assumptions and their associated uncertainties. Therefore, the present research will provide a new methodological and analytical contribution to the field, by approaching the epistemological challenge of beach complexity and beach quality indexes.

\section{Methods}

The identification of indexes of beach sustainability was performed through a Scopus search using the terms "beach" and "indexes". Those approaching the beach as a multidimensional system (Table 1) were selected.

The knowledge assessment of the abovementioned indexes was conducted through a methodological set delineated hereinafter, as it was approached chronologically. Twenty-five main assumptions (Appendix I) were identified and scored. We identified/tested "in situ", with the support of stakeholders of the Catalan coast, assumptions 2, and 7 to 25, of Appendix I, which belong to the BQI (developed for the Catalan coast). The assessment was, thus, extended to assumptions of the rest of the selected indexes (assumptions 1 to 6 of Appendix I). Later in the present article, we discuss the ten weakest assumptions resulting from the whole process.

\subsection{Pre-identification of assumptions: highlighting of dimensions and narratives of the Catalan coast}

A multi-stakeholder meeting was held in Barcelona on April 1st 2016, to co-define beach management dimensions, narratives and priorities of the Catalan coast. Present at the meeting were fifty-seven stakeholders from the three levels of government (i.e. state, regional and municipal), the private sector (e.g. consulting firms and certification organizations), academic institutions, the organized civil society (e.g. citizens' platforms for the environment) and a combination of the aforesaid types (e.g. clusters for the development of nautical activities). It was the first known attempt at integrating the organized civil society on the scale of Catalonia. In a joint manner, the assistants highlighted and discussed the most prominent coastal issues. By adapting the Participative Planning and Associate Management methodology (Poggiese, 1993), the meeting identified:

\subsubsection{Dimensions composing the Catalan beach SES}

Following Munda (2005), for this research, dimensions were conceptualized as a level of analysis broad enough to display specific objectives, indicators and variables. Dimensions comprise one or more 
BQI functions and elements. For instance, the morphodynamics dimension includes the protection function of beaches, but also other elements, such as sediment transport.

Beach SES dimensions in the Catalan coast are: 1. Recreational activity, 2. Morphodynamics, 3. Ecology and natural heritage, 4. Beach economics, and 5. Governance and management. Due to the complexity of this last dimension, which would require more in-depth analysis, we decided not to directly explore it in this study.

\subsubsection{Narratives of the Catalan coast}

Differences in societal values, perspectives and interests are manifested through narratives, i.e. the 'story' explaining them (Garnåsjordet et al., 2012). The objective(s) of any study related to management, as is the case of the assessment tools, is the reflection of the narrative(s) being taken into account. Thus, when characterized, narratives support the identification of biases underlying the beach indexes. For the Catalan coast, the following were delineated as prevalent (Molina, 2016):

1. Economic growth: Beaches are a resource for tourism and leisure;

2. Sustainable development: Beaches are natural and public spaces. Tourism is one of the main economic activities of the coast. There is a need for regulations, social inclusion and environmental protection;

3. Integrated coastal zone management: Beaches are a natural space. Management is too focused on tourism services and facilities. There is a need for integrative principles and a systemic view;

4. Environmental protection: Beaches are natural spaces of great ecological importance. It is essential to protect the coastal zone, especially because only a few areas are not highly impacted by human activities.

The different process and relations occurring inside and between one or more dimensions were explained by the stakeholders using one or more narrative(s), i.e. these are distributed transversally across the dimensions (Molina, 2016).

\subsection{Identification and assessment of assumptions}

The authors compiled a list of twenty-five main assumptions (Appendix I) by contrasting the processes of creation on the selected indexes with the aforesaid analysis and the literature on socioecologi- cal indicators (e.g. Martinez-Alier et al., 1998, Munda, 2005, Garnåsjordet et al., 2012, Giampietro and Saltelli, 2014). Since our first motivation was to verify if beaches were truly approached as SES, the search for assumptions focused on the partiality of the conceptualizations (pre-analytical choices (Kovacic, 2015)) behind the structure of the beach quality indexes.

Scientific assumptions may connect different related concepts, as seen in Van der Sluijs and Wardekker (2015), so making assumptions explicit may reduce the bias of assessments, increase the quality of the knowledge base and improve uncertainty assessment (Kloprogge et al., 2011). It is worth mentioning, though, that authors building the assumptions may also display particular limits of knowledge and perspectives (Kloprogge et al., 2011). To minimize the arbitrariness and subjectivity of qualitative expert judgement (Van der Sluijs et al., 2003), in this study, assumptions were assessed through the criteria displayed in the pedigree matrix of Table 2 , according to which scores could be identified within a weakness range of 0 (low) to 4 (high).

The pedigree criterions (Van der Sluijs and Wardekker, 2015) are:

- Influence of resource limitations: This evaluates whether the assumption has been included because of resource limitations (such as data, money, time, software, human resources, etc.). Without these, the analyst would have incorporated a different assumption.

- (Im) Plausibility: This values the level of agreement, mostly based on an (intuitive) assessment, between the assumption and the 'reality' observed.

- Choice space: This analyzes the number of alternative assumptions available beyond the assumption chosen. In general, one can say that a larger choice space makes the analyst's preferences more arbitrary.

- (Dis)Agreement among peers: The agreement or disagreement of the peers in this body of knowledge is valued in the selection of the assumption. This may vary in the different bodies of knowledge.

- Analyst's objectivity: This analyzes the extent to which the assumption can be influenced, consciously or unconsciously, by the preferences of the analyst: views, interests, cultural background, discipline and personal.

- Influence on the global outcomes of the dimension(s) in question: This evaluates the impact that the choice of the assumption could have on the end result of the dimension in question.

Table 2

Pedigree assessment matrix. Source: Adapted from Van der Sluijs and Wardekker (2015).

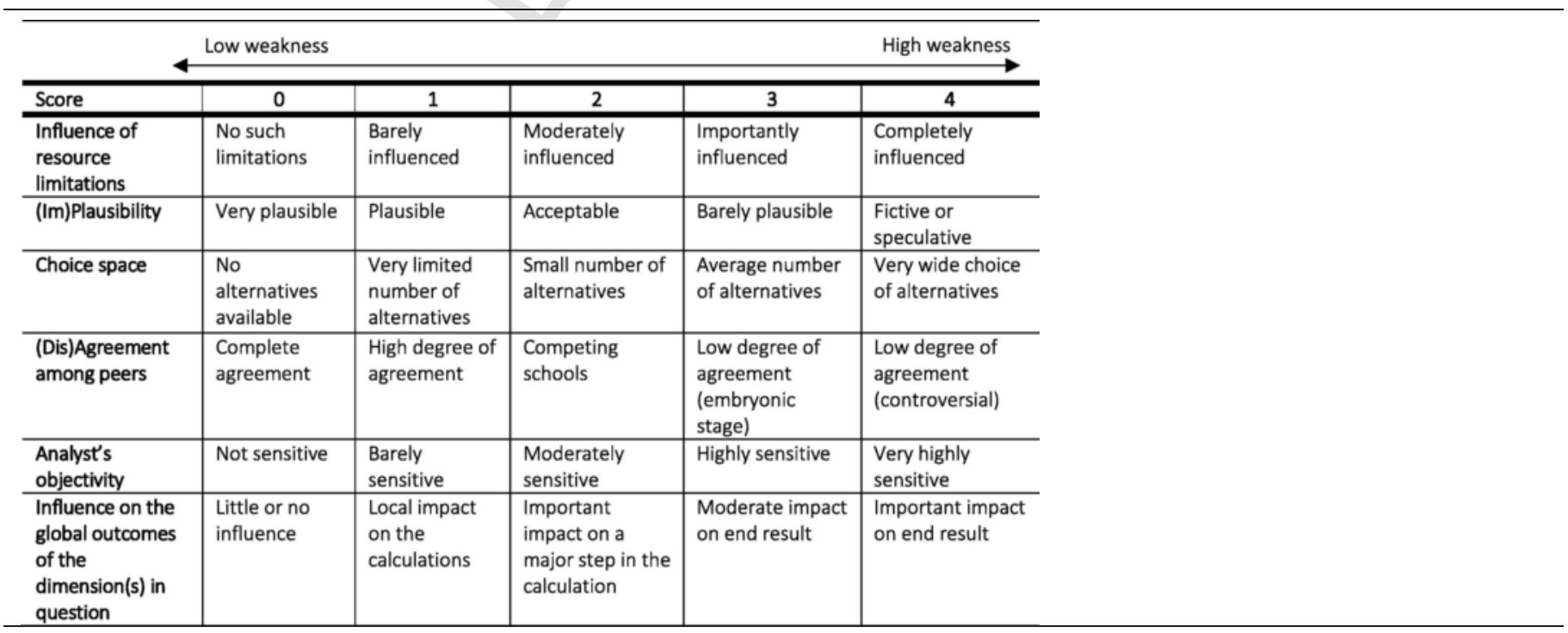




\subsubsection{The case of Catalonia: assessment of the BQI assumptions}

From the twenty-five list, those assumptions related to the BQI (assumptions 2, and 7-25) were tested "in situ" (by Catalan coastal stakeholders), before the identification and scoring of assumptions present in all selected indexes. The aforesaid test was performed by focus groups (FGs) and one online questionnaire, applying the pedigree matrix (Table 2 ) in an extended peer review process. This review process also checked the influence of the present authors' particular biases (Kloprogge et al., 2011), by an initial assessment, in each FG, of the written assumptions. 3.2.1.1. The development of the focus groups We organized and carried out four FGs (Table 3), each of them corresponding to the beach dimensions identified at the multi-stakeholder meeting which, in turn, are explained by one or more narratives (right column of Table 3). In total, 24 representatives of different institutions attended the meetings, satisfying requirements on FGs methodologies (Bryman, 2012). First, the BQI sub-indexes related to the specific FG subject were presented. Second, we reviewed the writing of the corresponding assumptions by reading and discussing them in a joint manner. Finally, we combed the assumptions through the application of the pedigree matrix.

3.2.1.2. Online questionnaires An online survey (in www.surveymonkey.com) was used as a complementary tool to test the assumptions of the ecology and natural heritage dimension, i.e. assumptions $2,16,17$, 18 and 19 of Appendix I. Four experts evaluated these assumptions using the pedigree matrix. Concomitantly, they were asked to comment on the identification and writing of the beach assumptions.

\subsubsection{Expansion of the Catalan test: review, comparison and highlighting of assumptions}

The procedures followed to assess assumptions of the BQI enabled the authors to finally specify the assumptions related to all beach quality indexes considered (assumptions 1 to 6 in Appendix I), to which they also inferred pedigree scores (application of Table 2). These assumptions were identified, written and scored by the authors of the research. This process served to start a broad discussion about the quality of knowledge produced in the field of beach assessment tools.

Due to differences in the subjects approached and in the scoring given by each group of stakeholders, we reviewed and homologated the pedigree scores deployed for both the BQI and all indexes' assumptions. It served to establish comparisons between assumptions and, especially, highlight the ten weakest ones, i.e. those presenting the higher scores on the average pedigree and the influence on global outcomes criteria. We focused our discussion on these ten weakest assumptions. In order to clarify this, we present a scoring table (Table 4) and diagram (Fig. 3) in the next section.

\section{Results and discussion}

\subsection{Robustness of the indexes}

Table 4 presents the scores assigned to the ten weakest assumptions. They were revealed to be somewhat robust (average pedigree score is 1.6 out of 4). The most important weaknesses were detected, respectively, for (im)plausibility (2.3), choice space (2), the analysts' objectivity (1.8), (dis)agreement between peers (1.8) and the influence on resource limitations (1.5). The influence on global outcomes, though analysed aside, presented the highest score (2.6).

\subsubsection{Individual analysis of key assumptions}

I- The observation (and measurement) of the processes related to recreational activities, natural heritage and ecology, and the morphodynamics of beaches are sufficient for analysing the sustainability of these SES

Table 3

Structure of the FGs regarding the sub-indexes and narratives approached, and the number and profile of the participants.

\begin{tabular}{|c|c|c|c|c|}
\hline Focus group & Corresponding sub-indexes & \multicolumn{2}{|c|}{ Participants } & \multirow[t]{2}{*}{ Main narratives approached } \\
\hline & & $\mathrm{N}^{\circ}$ & Main profiles & \\
\hline $\begin{array}{l}\text { Recreational } \\
\text { activity }\end{array}$ & $\begin{array}{l}\text { Microbiological water quality", Beach } \\
\text { crowding, Environmental quality, Services } \\
\text { and facilities, Activities, Access and } \\
\text { parking, Comfort quality and Beach Safety }\end{array}$ & 6 & $\begin{array}{l}\text { Academic peers: } 1 \text { Social perception expert, } 2 \text { Coastal } \\
\text { tourism and leisure experts, } 1 \text { Integrated beach } \\
\text { management expert } \\
\text { Local government: } 1 \text { Decision maker on environmental } \\
\text { affairs, } 1 \text { Specialist in reduced mobility }\end{array}$ & Economic growth \\
\hline $\begin{array}{l}\text { Ecology and } \\
\text { natural } \\
\text { heritage }\end{array}$ & $\begin{array}{l}\text { Surrounding area quality, the Natural } \\
\text { conditions and the Water body ecological } \\
\text { and chemical status* }\end{array}$ & 5 & $\begin{array}{l}\text { Academic peers: } 1 \text { Integrated beach management } \\
\text { expert, } 1 \text { Coastal geography expert } \\
\text { Regional administration: } 1 \text { Specialist in Landscape } \\
\text { planning } \\
\text { Consulting company: } 1 \text { Coastal information maker and } \\
\text { user } \\
\text { Organized civil society: } 1 \text { Environmental protection } \\
\text { activist }\end{array}$ & $\begin{array}{l}\text { Environmental protection, } \\
\text { Integrated coastal zone } \\
\text { management }\end{array}$ \\
\hline $\begin{array}{l}\text { Morpho- } \\
\text { dynamics }\end{array}$ & Physical Quality and Protection & 6 & $\begin{array}{l}\text { Academic peers: } 2 \text { Coastal geology experts, } 1 \text { Coastal } \\
\text { engineering expert } \\
\text { State administration: } 2 \text { Specialists in Coastal } \\
\text { engineering } \\
\text { Consulting company: } 1 \text { Specialist in beach restoration }\end{array}$ & $\begin{array}{l}\text { Economic growth, } \\
\text { Sustainable development }\end{array}$ \\
\hline Economics & $\begin{array}{l}\text { Economic valuation methods available, } \\
\text { specifically the Travel Cost Method and the } \\
\text { Hedonic Prices }\end{array}$ & 7 & $\begin{array}{l}\text { Academic peers: } 1 \text { Economic geography expert, } 1 \\
\text { Coastal geography expert, } 1 \text { Integrated beach } \\
\text { management expert, } 1 \text { Sustainability expert, } 1 \text { Tourism } \\
\text { economy expert, } 1 \text { Coastal economy expert, } 1 \\
\text { Information systems expert }\end{array}$ & $\begin{array}{l}\text { Economic growth, } \\
\text { sustainable development } \\
\text { and Integrated coastal zone } \\
\text { management }\end{array}$ \\
\hline
\end{tabular}

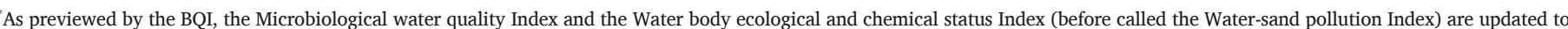
the new EU requirements, respectively, the Directive 2006/7/EC and the Directive 2000/60/EC 
Table 4

Pedigree score of the selected assumptions.

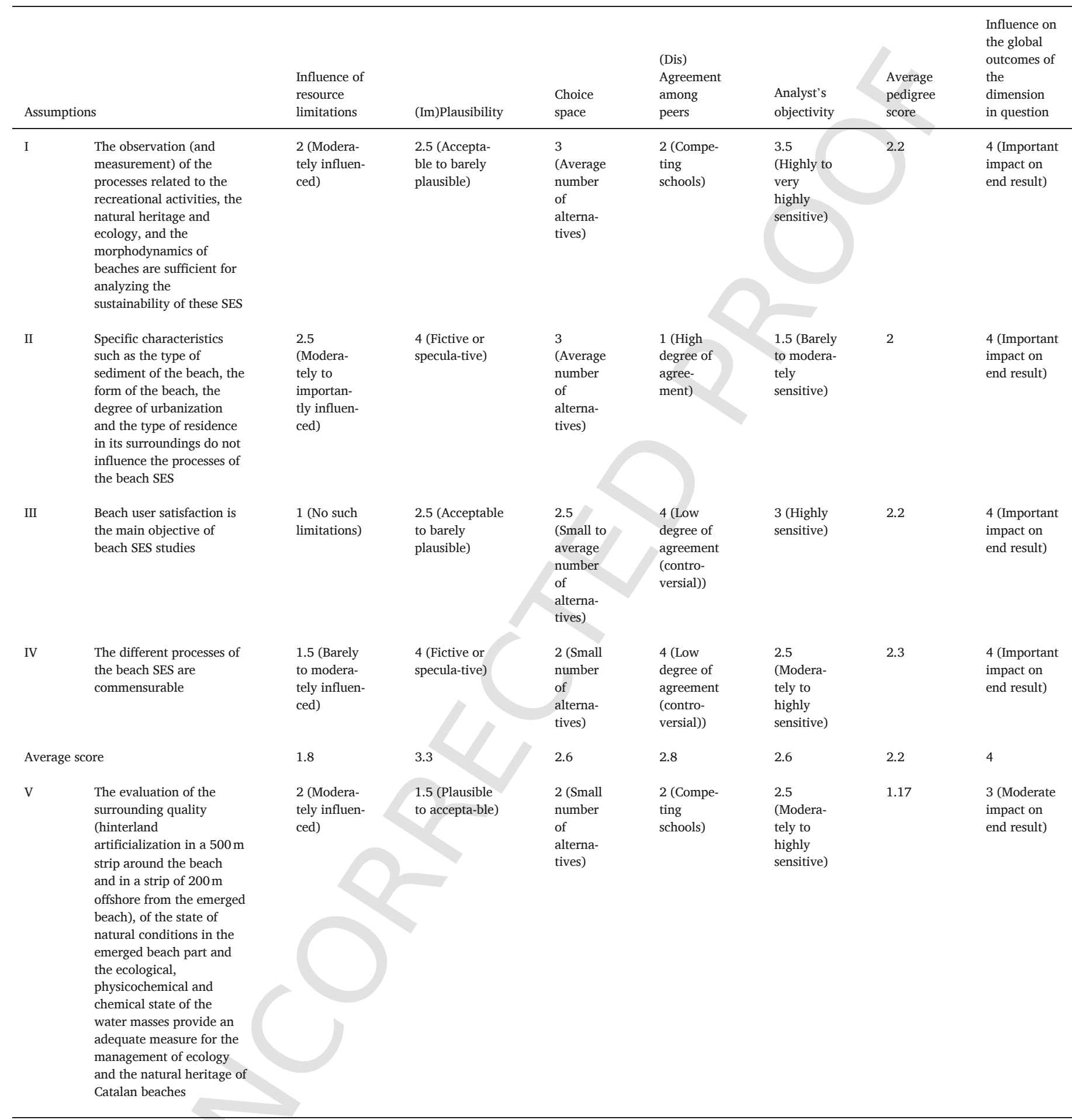




\begin{tabular}{|c|c|c|c|c|c|c|c|c|}
\hline \multicolumn{2}{|c|}{ Assumptions } & \multirow{2}{*}{$\begin{array}{l}\begin{array}{l}\text { Influence of } \\
\text { resource } \\
\text { limitations }\end{array} \\
3 \text { (Impor- } \\
\text { tantly } \\
\text { influen-ced) }\end{array}$} & \multirow{2}{*}{$\begin{array}{l}\text { (Im)Plausibility } \\
2.5 \text { (Accep- } \\
\text { table to barely } \\
\text { plausible) }\end{array}$} & \multirow{2}{*}{$\begin{array}{l}\begin{array}{l}\text { Choice } \\
\text { space }\end{array} \\
3 \\
\text { (Average } \\
\text { number } \\
\text { of } \\
\text { alterna- } \\
\text { tives) }\end{array}$} & \multirow{2}{*}{ 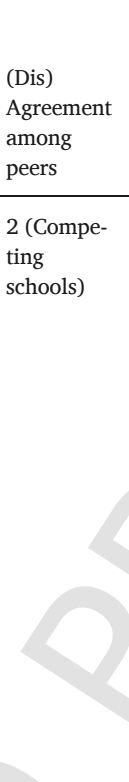 } & \multirow{2}{*}{$\begin{array}{l}\begin{array}{l}\text { Analyst's } \\
\text { objectivity }\end{array} \\
1.5 \text { (Barely } \\
\text { to modera- } \\
\text { tely } \\
\text { sensitive) }\end{array}$} & \multirow{2}{*}{$\begin{array}{l}\begin{array}{l}\text { Average } \\
\text { pedigree } \\
\text { score }\end{array} \\
2\end{array}$} & \multirow{2}{*}{$\begin{array}{l}\begin{array}{l}\text { Influence on } \\
\text { the global } \\
\text { outcomes of } \\
\text { the } \\
\text { dimension } \\
\text { in question }\end{array} \\
2 \text { (Important } \\
\text { impact on a } \\
\text { major step } \\
\text { of the } \\
\text { calculation) }\end{array}$} \\
\hline VI & $\begin{array}{l}\text { The monitoring of the } \\
\text { state (and potential) of the } \\
\text { dune system is adequate } \\
\text { and sufficient to } \\
\text { determine the natural } \\
\text { heritage of the emerged } \\
\text { part of Catalan beaches. } \\
\text { This state (and potential) } \\
\text { is determined by the } \\
\text { numerical evaluation of } \\
\text { the presence of typical } \\
\text { dune system flora species } \\
\text { in Catalonia, the extension } \\
\text { of the dune vegetation } \\
\text { area in relation to the } \\
\text { wind controlled part of } \\
\text { the beach and the visual } \\
\text { assessment of the } \\
\text { dimension of the habitat }\end{array}$ & & & & & & & \\
\hline VII & $\begin{array}{l}\text { Beach morphodynamics } \\
\text { should be assessed by } \\
\text { analyzing beach capacity } \\
\text { for coastal protection and } \\
\text { human impacts on beach } \\
\text { physical structure }\end{array}$ & $\begin{array}{l}1 \text { (No such } \\
\text { limita-tions) }\end{array}$ & 2 (Accepta-ble) & $\begin{array}{l}2 \text { (Small } \\
\text { number } \\
\text { of } \\
\text { alterna- } \\
\text { tives) }\end{array}$ & $\begin{array}{l}2 \text { (Compe- } \\
\text { ting } \\
\text { schools) }\end{array}$ & $\begin{array}{l}2.5 \text { (Mode- } \\
\text { rately to } \\
\text { highly } \\
\text { sensitive) }\end{array}$ & 1.6 & $\begin{array}{l}3 \text { (Moderate } \\
\text { impact on } \\
\text { end result) }\end{array}$ \\
\hline VIII & $\begin{array}{l}\text { The effective width of the } \\
\text { beach, the storm reach } \\
\text { and the minimum width } \\
\text { of the beach enable a good } \\
\text { representation of the } \\
\text { capacity of beaches for } \\
\text { coastal protection. The use } \\
\text { of the SBeach model is } \\
\text { adequate to calculate } \\
\text { beach protection capacity } \\
\text { on Catalan beaches }\end{array}$ & $\begin{array}{l}2.5 \text { (Mode- } \\
\text { rately to } \\
\text { importan- } \\
\text { tly influen- } \\
\text { ced) }\end{array}$ & $\begin{array}{l}2.5 \text { (Acceptable } \\
\text { to barely } \\
\text { plausible) }\end{array}$ & $\begin{array}{l}2 \text { (Small } \\
\text { number } \\
\text { of } \\
\text { alterna- } \\
\text { tives) }\end{array}$ & $\begin{array}{l}2 \text { (Compe- } \\
\text { ting } \\
\text { schools) }\end{array}$ & $\begin{array}{l}1 \text { (Barely } \\
\text { sensitive) }\end{array}$ & 1.7 & $\begin{array}{l}2 \text { (Important } \\
\text { impact on a } \\
\text { major step } \\
\text { of the } \\
\text { calculation) }\end{array}$ \\
\hline IX & $\begin{array}{l}\text { The anthropogenic } \\
\text { impacts on the physical } \\
\text { quality of beaches can be } \\
\text { identified by the changes } \\
\text { in grain size, beach } \\
\text { surface and wave regime }\end{array}$ & $\begin{array}{l}2 \text { (Mode- } \\
\text { rately } \\
\text { influen-ced) }\end{array}$ & $\begin{array}{l}2.5 \text { (Accepta- } \\
\text { ble to barely } \\
\text { plausible) }\end{array}$ & $\begin{array}{l}1 \text { (Very } \\
\text { limited } \\
\text { number } \\
\text { of } \\
\text { alterna- } \\
\text { tives) }\end{array}$ & $\begin{array}{l}1 \text { (High } \\
\text { degree of } \\
\text { agree- } \\
\text { ment) }\end{array}$ & $\begin{array}{l}1 \text { (Barely } \\
\text { sensitive) }\end{array}$ & 1.3 & $\begin{array}{l}2 \text { (Important } \\
\text { impact on a } \\
\text { major step } \\
\text { of the } \\
\text { calculation) }\end{array}$ \\
\hline $\mathrm{X}$ & $\begin{array}{l}\text { All values of beaches can } \\
\text { be expressed in monetary } \\
\text { terms }\end{array}$ & $\begin{array}{l}1 \text { (No such } \\
\text { limita-tions) }\end{array}$ & $\begin{array}{l}4 \text { (Fictive or } \\
\text { specula-tive) }\end{array}$ & $\begin{array}{l}3 \\
\text { (Average } \\
\text { number } \\
\text { of } \\
\text { alterna- } \\
\text { tives) }\end{array}$ & $\begin{array}{l}2 \text { (Compe- } \\
\text { ting } \\
\text { schools) }\end{array}$ & $\begin{array}{l}3 \text { (Highly } \\
\text { sensitive) }\end{array}$ & 2.2 & $\begin{array}{l}3 \text { (Moderate } \\
\text { impact on } \\
\text { end result) }\end{array}$ \\
\hline \multicolumn{2}{|c|}{ Average score } & 1.9 & 2.5 & 2.2 & 1.8 & 1.9 & 2.6 & 2.5 \\
\hline \multicolumn{2}{|c|}{ Average total score } & 1.5 & 2.3 & 2 & 1.8 & 1.8 & 1.6 & 2.6 \\
\hline
\end{tabular}

The management tools analysed presented sub-indexes corresponding predominantly to the dimensions of recreational activities, natural heritage and morphodynamics, marginalizing others, such as those highlighted by the multi-stakeholder participatory meeting or by some of the indexes (e.g. the BEI, BQI, BHI and IBVI of Table 1), i.e. the dimensions of beach economics, integrated management-governance, and culture and religion-spirituality. Our case experience showed that the beach SES would be better understood if indexes also accounted for the marginalized dimensions, by addressing their explanatory narratives and transforming into new sub-indexes (with particular objectives). In other words, a more holistic view of the beach is needed.

II- Specific characteristics such as the type of beach sediment, the form of the beach, the degree of urbanization and the type of residence in its surroundings do not influence the processes of the beach SES 

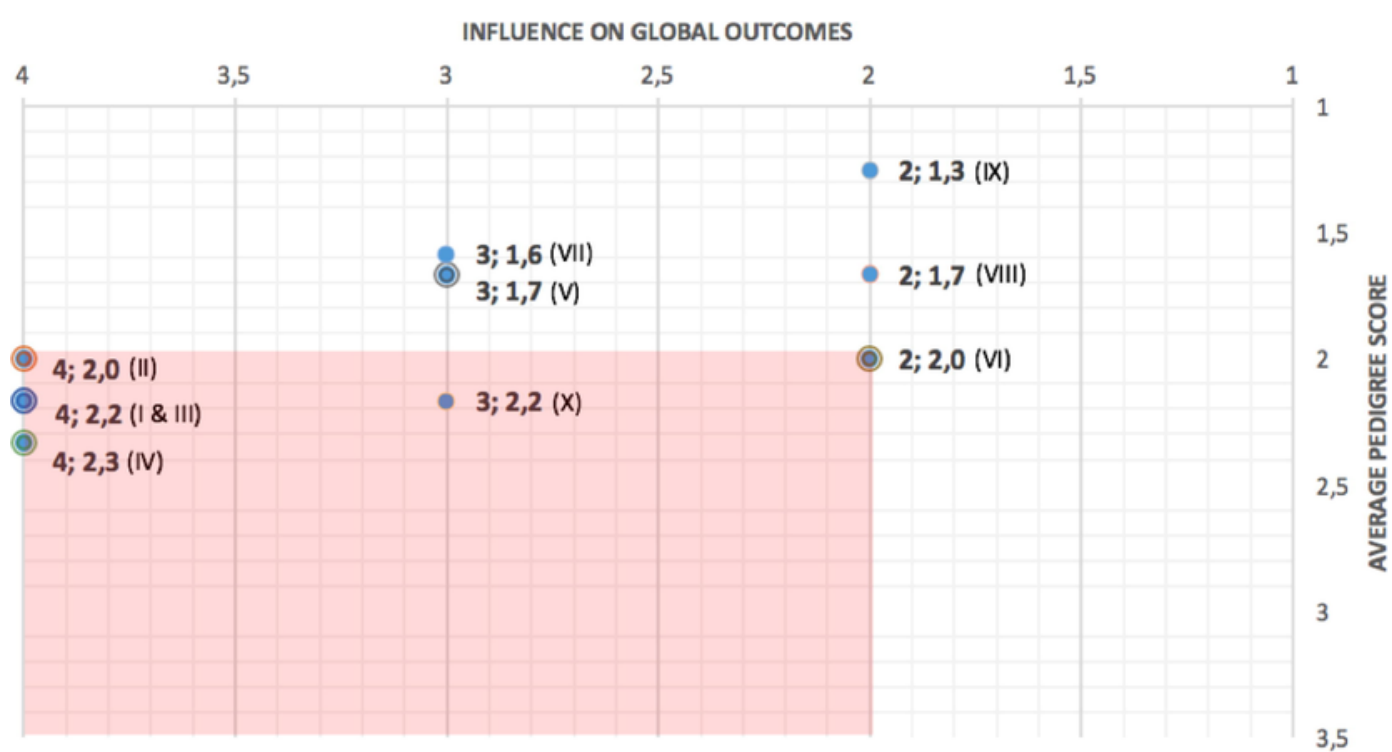

Legend:

Most critical assumptions

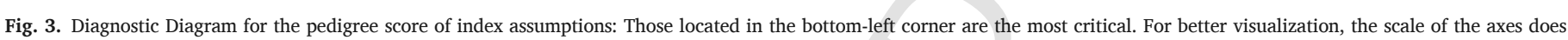
not correspond to that of the criteria $(0-4)$.

In spite of the partial recognition by those who developed the studied indexes of the influence of specific beach characteristics on the SES elements or processes, the majority of their sub-indexes did not include variables to address it. Exceptions are found in the sub-indexes of services and facilities (in the BQI, the index by Semeoshova et al. and the $\mathrm{BHI}$ ), which account for the degree of urbanization in beach surroundings. If sub-indexes do not differentiate the characteristics (local specificities) needed for a robust evaluation, the state of the different beach elements or processes is not properly assessed. Resource limitations demand prioritization of those most relevant for each sub-index. For example, the degree of urbanization, while central to services and facilities, would not directly influence user comfort, which includes aspects of the beach structure (e.g. slope, width) and climatic conditions.

\section{III- Beach user satisfaction is the main objective of beach studies}

Beach user satisfaction, supported by those narratives corresponding to tourism and leisure (economic growth and partially sustainable development; Molina, 2016), seems to prevail over other beach management objectives in all indexes. In the BQI, the sub-indexes corresponding to the recreational activity dimension are predominant. Even when sub-indexes for the dimensions of morphodynamics and natural heritage and ecology are included, this is done with the aim of promoting certain types of recreation. For instance, variables for measuring litter management are especially focused on the potential impacts on users' perception, rather than other impacts more linked with the overall SES. It is worth mentioning, though, that this assumption would increase in plausibility when the focus of studies is on those beaches with higher levels of urbanization and usually with more services and facilities (Lozoya et al., 2014).

As recognized by the authors of the indexes (Ariza et al., 2010, Botero et al., 2015, Cervantes and Espejel, 2008, Semeoshenkova et al., 2015, Todd and Bowa, 2016, Lucrezi et al., 2016), these were mainly built for recreational beaches, emphasizing a preference towards beach user satisfaction. However, the constraint of the analysis to only one objective (i.e. promote user satisfaction) will not adequately explain the complexity of the beach processes and interrelations. Socioecologi- cal processes occurring on beaches do not cease just because these are mainly managed as recreational spaces, thus sub-indexes responding to other SES processes rather than recreational activity should also be included. This assumption obstructs more integrated and collective conceptualizations (Bremer, 2013, Garnåsjordet et al., 2012), maintaining the reductionist view of the beach as a merely recreational space (James, 2000, Lozoya et al., 2014).

\section{IV- The different processes of the beach SES are commensurable}

The analysed tools make use of weighting and aggregating procedures (i.e. a calculation chain) in order to establish a single result, expressed by a number or evaluation class, and only rudimentarily deal with their embedded inexactness. Though the indexes sought to value the different non-equivalent representations of beaches (Kovacic, 2015), they assume that different assets, processes and interrelations can be compared and weighted in the same way, inadequately translating them into the practical sub-indexes and variables. In other words, they assume commensurability (Martinez-Alier et al., 1998).

Criticism regarding composite indexes, especially by some ecological economists, highlight that different non-equivalent representations of beaches cannot be reduced without the loss of relevant information and an inevitable conflict between narratives (Martinez-Alier et al., 1998, Munda, 2004, Giampietro and Saltelli, 2014). More time and new participatory tools and methods would be needed to better consider non-equivalent representations of the beach, but a shift to an incommensurable logic is the main priority in this direction. For example, the index by Semeoshenkova et al. (2015), despite using weighting (i.e. ranking the sub-indexes and variables) and a linear aggregation, has displayed the results through a radar chart that highlights the different dimensions analysed.

V- The evaluation of the surrounding quality (hinterland artificialization in a $500 \mathrm{~m}$ strip around the beach and in a strip of $200 \mathrm{~m}$ offshore from the emerged beach) of the state of natural conditions in the emerged beach part and the ecological, physicochemical and chemical state of the water masses provide an adequate measure for 
the management of ecology and the natural heritage of Catalan beaches

Although the sub-indexes of surrounding quality, natural conditions, and state of water masses encompass the main ecological/natural heritage processes occurring in the beach, part of its natural assets may be overlooked. In the case of Catalonia, suggestions for a more complete analysis of the dimension in question included sub-indexes for the measurement of geological values (e.g. ancient dunes), species of fauna (e.g. Charadrius alexandrinus) and submerged beach heritage (e.g. Mediterranean marine biogenic constructions).

VI- The monitoring of the state (and potential) of the dune system is adequate and sufficient to determine the natural heritage of the emerged part of Catalan beaches. This state (and potential) is determined by the numerical evaluation of the presence of typical dune system flora species in Catalonia, the extension of the dune vegetation in relation to the wind controlled part of the beach and the visual assessment of the dimension of the habitat

In the analysis of the ecology and natural heritage dimension (emerged part of the beach), it is assumed that its assessment would be sufficiently carried out through the monitoring of the aforesaid characteristics of the state of dune systems in Catalonia. Nonetheless, not all Catalan beaches have the potential for hosting natural dunes (Pintó et al., 2014). As observed by one of the respondents to the questionnaire: "sandy areas with coarser materials (that never form dune belts and, consequently, never deploy species of dune flora) may present a low conservation value despite being well preserved". A better adapted measurement to the Catalan context would value other assets of the emerged part of beaches, considering a wider range of beach types (not just those with potential dune systems). The observation of vegetation species other than those of dunes, as well as cliffs and communities of invertebrates has been discussed.

VII- Beach morphodynamics should be assessed by analysing beach capacity for coastal protection and human impacts on beach physical structure

The observation of other assets/processes besides capacity for coastal protection and human impacts on the physical structure would contribute to a wider view of the beach morphodynamics dimension. Some examples of these assets/process are those contributing toward coastal evolution (e.g. changing beach forms and, ultimately, coastal geomorphological features) and water filtration (by pressure changes in the bed of surf zones). Part of the bias given by the assumption relates to the usual prominence given to the protection function in beach management tools (James, 2000).

VIII- The effective width of the beach, the storm reach and the minimum width of the beach enable a good representation of the capacity of beaches for coastal protection. The use of the SBeach model is adequate to calculate beach protection capacity on Catalan beaches

The first factors that weaken this assumption's plausibility are the limitations of the model, SBeach, which estimates beach protection capacity through the calculation of the effective width of the beach, the storm reach and the minimum width of the beach. This model (Larson and Kraus 1989 in Thieler et al., 2000) was designed to predict beach and dune erosion caused by storms, and also the formation and movement of bars. It, then, assumes beach dynamics as a 1D process (cross-shore movement due to waves), despite being a 3D reality; no net loss or gain of sediments; and uniform longshore process (i.e. they are not considered) (Thieler et al., 2000). In addition, the model requires a calibration process in order to be applied in the study area, which is not usually carried out.

This assumption also excludes important conditions that decisively affect coastal protection, such as the height of the aerial part of sandy beaches and the beach rotation occurring in pocket beaches, as occurs in a significant part of the Catalan coast. The main alternative to this would be to carry out an analysis of the coastline evolution for each beach, enabling the identification of erosion/accretion trends. This, instead of estimating the effective width of the beach, the storm reach and the minimum width of the beach, would account for the identification of rates of coastline movement, which would indicate the potential of beaches for coastal protection. Other technical and methodological uncertainties would be embedded in this new alternative; nonetheless, it may reduce the demand for resources and include pocket beaches, making it a better-suited measurement for the Catalan reality.

IX- The anthropogenic impacts on the physical quality of beaches can be identified by the changes in grain size, beach surface and wave regime

The BQI assumes that non-anthropogenic (natural) processes are not capable of changing grain size, beach surface or wave regime. However, natural dynamics would also account for such changes in some coastal areas; for example, grain size may vary in beaches surrounding river mouths. Rivers are a transport agent contributing with sediments of variable grain size. In this sense, the present assumption may potentially mislead the estimation of anthropogenic impacts. As an alternative for calculating the anthropogenic impacts, a suggestion is made to directly check the existence of previous interventions (official engineering works) undertaken on the coastline (e.g. beach nourishment). Uncertainties regarding this method were emphasized, such as the non-identification of non-official sand nourishments; however it would decrease the demand of resources for the analysis.

\section{$\mathrm{X}$ - All beach values can be expressed in monetary terms}

All the economic valuation methods applied in the IBVI, BQI and BEI - the travel cost method (TCM)/hedonic pricing (HP) - are supported by the assumption in question, which is epistemological, grounded in the field of environmental economics. All beach values can be expressed in monetary terms, i.e. they are commensurate. In contrast, the ecological economics approach stands for the analysis of the socioecological systems through a plural framework, rather than trusting exclusively in monetary valuations, assuming the incommensurability of values and considering the complex relationships of SES.

Questions such as "Is it possible to put a monetary term on a particular species or process, which can deploy a variety of other values?" are highlighted (Funtowicz and Ravetz, 1994). Alternative suggestions to this assumption would entail a wider set of economic and non-economic valuations, such as multicriteria frameworks (Munda, 2005). Though this would possibly involve more resources, we infer that the election of this assumption is much more influenced by the pre-analytical choice for a certain conceptualization of beach valuations.

\subsubsection{Final assessment of the key assumptions}

The average pedigree score of each assumption was plotted against the results for influence on the global outcomes' criterion (Fig. 3; as in Kloprogge et al., 2011) in order to group the most critical ones. From the list of ten assumptions, six are placed in the bottom-left corner of the graph, demarcated by the light red area where both the average pedigree and the influence of results are $>=$ to 2 , corresponding to the "weakest quadrant". 
Following the aforementioned graphical representation, we summarized what we found to be the most important aspects of each criterion analysed, posing some examples of individual assumptions. The group of assumptions related to all indexes (I to IV) presented the highest average scores (high weakness) for all criteria in comparison with the assumptions strictly of the BQI (V to X), except for assumption X. This difference seems to be linked with a higher conceptual (and abstract) load of all index assumptions, which are responsible for defining the way sub-indexes are framed to represent the beach SES. The other assumptions (from the BQI) refer to more concrete questions and objectives.

In particular, the highest scores for the influence on the global outcomes criterion correspond to assumptions located in the highest hierarchy of the indexes (first or second level, see the BQI hierarchy in Fig. 1 ), and may be found in all indexes selected. Moreover, for example, assumption IX, which is the strongest of the ten, refers to a specific sub-index in the third level of the BQI. The influence on final outcomes may be beneficial or harmful for the quality of the assessment depending on whether the assumption is weak or strong. A high influence is positive in the case of strong assumptions (lower average pedigree of other criteria).

The (im)plausibility scores showed a gap between the indexes and the 'reality' they seek to represent. What the beach indexes claim to do and what they actually deliver lack correspondence (as in Giampietro and Saltelli, 2014), at least for those assumptions carrying a higher conceptual load. Models and indexes can be wrong when scientific judgment happens to be external to what is at play (Allen et al., 2017). Contrasting the narratives identified with both the results for analyst objectivity and the (dis)agreement between peers highlighted the role of the scientific background and interests in formulating the indexes.

The analysis showed a prioritization of the narratives related to sun, sea and sand recreation in all indexes, somehow still reproducing traditional approaches (James, 2000, Lozoya et al., 2014). If other narratives, such as environmental protection were included in a balanced way, different goals and attributes could have been added in the form of dimensions and sub-indexes. In fact, the dimensions of beach SES not directly related to narratives for the recreational activity development, shared a need for the inclusion of more sub-indexes to better attend their objectives (such as in assumptions V and VII) and to update the existing ones (e.g. assumption VIII).

Advising for other beach management objectives rather than recreation (and combining them in a management strategy of a particular beach) requires further developments, though some authors have already advanced in this matter. McLachlan et al. (2013) suggest the suitability of some beaches for displaying a mixed used (conservation and recreation) and Dadon (2018) suggests that successful beach management may deploy different objectives resulting from diverse intensities of three change drivers: the demand for quality services, public use and enjoyment, and the environmental sustainability.

The inclusion of new levels of complexity through the objectives of analysis can, if done properly, be a solution for existing problems (Allen et al., 2017). The very first step for (re) building indexes should be to include the plurality of narratives and external references, setting out the different beach dimensions, elements and specificities (Garnåsjordet et al., 2012, Mayumi and Giampietro, 2006) comprising this complex system. However, without the required reflexive processes of evaluation, we may not seek synthesis and harmonization (Podger et al., 2016), nor properly account for all existing narratives. We should, thus, accept different values, interests and positions for a particular framework of data and sub-indexes, which would support tackling the relevant assumptions.

The average score for choice space demonstrated that, although small, there is room for index updates that are capable of delivering more realistic approximations to complexity in the future. Alternatives to assumptions (re) emphasized the possibilities of including other narratives in the form of sub-indexes besides those focusing on recreational activities, and of including sub-indexes that are better suited to local specificities. In this regard, FGs participants suggested replacing some of the BQI-indexes with more realistic ones, that are more relevant to the Catalan case (e.g. assumptions VIII and IX) in spite of the uncertainties that these changes would imply, which highlighted the academic trend towards idealization above pragmatism (Arnott et al., 2016). Complementarily, observing that the lowest average weakness scores were found for the criterion of influence of resource limitations, we inferred that the further improvement of better suited sub-indexes would not necessarily depend on more resources.

As already mentioned in Methods (Section 3), the identification and assessment of assumptions is not an objective process (Kloprogge et al., 2011), but doing so by including the proper participation of suitable stakeholders may help improve the management of uncertainties (Mayumi and Giampietro, 2006). The constant exchange between beach stakeholders and the attempt at identifying and reporting the main flaws of beach indexes should be promoted (Martínez and Dopheide, 2014). Development of the indexes based on an opening up of science, with greater public scrutiny and focus on precaution, could lead to more democratic, legitimized and creative results (Bremer and Glavovic, 2013). We, therefore, recommend more in-depth NUSAP analysis for each of all indexes approached in this study. Also, an extension of the NUSAP analysis to indexes tackling other coastal areas and issues (e.g. vulnerability indexes) may be appreciated. This would build capacity on the process of knowledge assessment, generate inclusive dynamics and improve the discussion around uncertainties in coastal management.

\section{Conclusions}

The analysis carried out indicated that the assumptions are slightly robust, though attention should be especially paid to the criteria of influence on global outcomes, (im)plausibility and choice space. The highest scores (weakest) corresponded to the "all indexes' assumptions", which deployed an abstract nature (lower correspondence with particular objectives) and higher conceptual loads. For instance, the weakest assumption (number IV) is conceptual loaded by the choice for commensurability analysis, which leads to comparisons of different non-equivalent representations of the beach SES in all indexes, at least in their higher levels of hierarchy, and without a proper process of reporting.

The studied indexes addressed the complexity of recreational beaches in a limited way. Their assessments are biased, and do not completely account for alternative types of recreation and processes (ecological, economic and morphodynamics) important for their sustainability. In most cases, the way in which the results of the indexes are deployed do not reflect non-equivalent representations of the beach system, even when the focus on the recreational activity dimension was partially balanced by the inclusion of other dimensions. They also report the embedded uncertainties in an insufficient way. As regards the $\mathrm{BQI}$ assumptions, their higher contextualization and correspondence to more concrete objectives led to lower average pedigree scores (more robustness), although the analysis reflected the predominance of the narratives of economic growth and sustainable development, also setting a focus on recreation. Other narratives suggested the need for new or adapted sub-indexes and dimensions.

A difficulty was observed upon putting into practice the complex systems discourse when structuring all indexes. This was especially denounced by the average score of (im)plausibility for all assumptions and by a tendency to rely on decontextualized scientific data. Specificities regarding particular narratives, processes, and manifestations of complexity (e.g. epistemological and ontological diversity) need to be 
recognized and taken into account by the science-policy interface, whenever possible. For example, irreducible uncertainty means that even if ecology and natural heritage sub-indexes present high values of conservation, negative interactions may be happening, and might be a direct threat to certain species due to changes in a non-observed variable.

The identified areas for improvement in all indexes reinforced the potential of the PNS approach for supporting the knowledge quality assessment. The observation of different narratives made a more holistic understanding of beach SES conceivable. The present analysis was especially useful for finding and evaluating conceptual-loaded assumptions embedded in all indexes and for reiterating that the influence of case dependency on the definition of concrete objectives (seen in the BQI assumptions) may support more robust assessments.

Finally, it is important to note that the call to open up and pluralize science discussed in this study does not seek to deny the specialized competence of scientists, but rather to position them as one further element in the framework of possible beach epistemologies.

\section{Declaration of interest}

None.

\section{Acknowledgements}

The first author had the support of the Ministry of Education (Brazil) by a CAPES Fellowship (99999.001355/2015-05). Eduard Ariza acknowledges support by a Ramón y Cajal contract (RYC-2013-13392) from the Ministerio de Economía y Competitividad (Spain). This research was developed under the framework of POLICIMA project (CSO2016-76842-C2-1-R) (Spain). Finally, both authors acknowledge the centrality and sincerely thank all the participants of this study.

\section{Appendix A. Supplementary data}

Supplementary data associated with this article can be found, in the online version, at https://doi.org/10.1016/j.ecolind.2018.03.066.

\section{References}

Allen, T.F.H., et al., 2017. Mapping Degrees of Complexity, Complicatedness, and Emergent Complexity, Ecol. Complexity, in press.

Ariza, E., et al., 2008. Beyond performance assessment measurements for beach management: application to spanish mediterranean beaches. Coastal Manage. 36 (1), 47-66.

Ariza, E., et al., 2010. Proposal for an integral quality index for urban and urbanized beaches. Environ. Manage. 45 (5), 998-1013.

Ariza, E., et al., 2012. On the relationship between quality, users' perception and economic valuation in nw mediterranean beaches. Ocean Coastal Manage. 63, 55-66. https:// doi.org/10.1016/j.ocecoaman.2012.04.002.

Ariza, E., et al., 2016. Is socio-ecological culture really being taken into account to manage conflicts in the coastal zone? Inputs from Spanish mediterranean beaches. Ocean Coastal Manage. 134, 183-193.

Arnott, J.C., et al., 2016. Evaluation that counts: a review of climate change adaptation indicators \& metrics using lessons from effective evaluation and science-practice interaction. Environ. Sci. Policy 66, 383-392.

Botero, C., Hurtado, Y., 2009. Tourist beach sorts as a classification tool for integrated beach management in Latin America. Coastline Rep. 13, 133-142.

Botero, C., et al., 2015. Design of an index for monitoring the environmental quality of tourist beaches from a holistic approach. Ocean Coastal Manage. 108, 65-73.

Bremer, S., 2013. Framing a 'post-normal' science-policy interface for integrated coastal zone management. In: Global Challenges in Integrated Coastal Zone Management. John Wiley \& Sons Ltd., pp. 179-191.

Bremer, S., Glavovic, B., 2013. Mobilizing knowledge for coastal governance: re-framing the science-policy interface for integrated coastal management. Coastal Manage. 41 (1), 39-56.

Bryman, A., 2012. Social Research Methods. Oxford University Press.

Cervantes, O., Espejel, I., 2008. Design of an integrated evaluation index for recreational beaches. Ocean Coastal Manage. 51 (5), 410-419.
Dadon, J.R., 2018. Beach management, beyond the double standard for client demands and environmental sustainability. In: Beach Management Tools - Concepts, Methodologies and Case Studies, Spring, 619-634.

Defeo, O., McLachlan, A., 2005. Patterns, processes and regulatory mechanisms in sandy beach macrofauna: a multi-scale analysis. Mar. Ecol. Prog. Ser. 295, 1-20.

Fraguell, R., et al., 2016. After over 25 years of accrediting beaches, has blue flag contributed to sustainable management?. J. Sustainable Tourism 24 (6), 882-903.

Fraguell, R., et al., 2013. Las Certificaciones Ambientales Como Sistemas de Gestión de Los Usos Recreativos de Las Playas. In: Hacia Un Nuevo Modelo Integral de Gestión de Playas. Documenta Universitaria, Girona, Spain, pp. 15-28.

Funtowicz, S.O., Ravetz, J.R., 1990. Uncertainty and Quality in Science for Policy. Kluwer Academic Publishers.

Funtowicz, S.O., Ravetz, J.R., 1994. The worth of a songbird: ecological economics as a post-normal science. Ecol. Econ. 10 (3), 197-207.

Funtowicz, S., Ravetz, J.R., 1990. La Ciencia Posnormal: Ciencia Con La Gente.

Garnåsjordet, P.A., et al., 2012. Sustainable development indicators: from statistics to policy. Environ. Policy Governance 22 (5), 322-336.

Giampietro, M., Saltelli, A., 2014. Footprints to nowhere. Ecol. Indicators 46, 610-621. https://doi.org/10.1016/j.ecolind.2014.01.030.

James, R.J., 2000. From beaches to beach environments: linking the ecology, human-use and management of beaches in Australia. Ocean Coastal Manage. 43 (6), 495-514.

Kloprogge, P., et al., 2011. A method for the analysis of assumptions in model-based environmental assessments. Environ. Modell. Software 26 (3), 289-301.

Kovacic, Z., 2015. Complexity Theory in Quality Assessment: Case Studies in Sustainability Science for Governance. Universitat Autònoma de Barcelona (UAB).

Laes, E., et al., 2011. On the contribution of external cost calculations to energy system governance: the case of a potential large-scale nuclear accident. Energy Policy 39 (9), 5664-5673.

Leatherman, S.P., 1997. Beach rating: a methodological approach. J. Coastal Res. 13 (13), 253-258

Lozoya, J.P., et al., 2014. Users expectations and the need for differential beach management frameworks along the costa brava: urban vs. natural protected beaches. Land Use Policy 38, 397-414.

Lucrezi, S., et al., 2015. Managing beaches and beachgoers: lessons from and for the blue flag award. Tourism Manage. 48, 211-230.

Lucrezi, S., et al., 2016. An assessment tool for sandy beaches: a case study for integrating beach description, human dimension, and economic factors to identify priority management issues. Ocean Coastal Manage. 121, 1-22.

Martinez-Alier, J., et al., 1998. Weak comparability of values as a foundation for ecological economics. Ecol. Econ. 26 (3), 277-286.

Martínez, J., Dopheide, E., 2014. Indicators: from counting to communicating. J. Educ Built Environ. 9 (1), 1-19.

Mayumi, K., Giampietro, M., 2006. The epistemological challenge of self-modifying systems: governance and sustainability in the post-normal science era. Ecol. Econ. 57 (3), 382-399.

McLachlan, A., et al., 2013. Sandy beach conservation and recreation: guidelines for optimising management strategies for multi-purpose use. Ocean Coastal Manage. 71 256-268.

Mir-Gual, M., et al., 2015. A critical view of the blue flag beaches in spain using environmental variables. Ocean Coastal Manage. 105, 106-115.

Molina, M., 2016. Percepcions Sobre Política Pública Costanera a Espanya: El Cas de Catalunya. Universitat Autònoma de Barcelona (UAB).

Morgan, R., 1999. A novel, user-based rating system for tourist beaches. Tourism Manage 20 (4), 393-410.

Munda, G., 2004. Social multi-criteria evaluation: methodological foundations and operational consequences. Eur. J. Operational Res. 158 (3), 662-677.

Munda, G., 2005. 'Measuring sustainability': a multi-criterion framework. Environ. Dev. Sustainability 7 (1), 117-134.

Pintó, J., et al., 2014. Assessing current conditions of coastal dune systems of mediterranean developed shores. J. Coastal Res. 30 (4), 832-842.

Poggiese, H., 1993. Metodología FLACSO de Planificación-Gestión (Planificación Participativa Y Gestión Asociada).

Ravetz, J., Funtowicz, S., NUSAP - The Management of Uncertainty and Quality in Quantitative Information. http://www.nusap.net/sections.php?op = viewarticle\&artid $=14$ (September 28, 2017).

Rosen, R., 1993. On models and modeling. Appl. Math. Comput. 56 (2-3), 359-372.

Sarewitz, D., 2004. How science makes environmental controversies worse. Environ. Sci Policy 7 (5), 385-403.

Seiffert, M.E., 2009. ISO 14.001 Sistemas de Gestão Ambiental: Implantação Objetiva E Econômica. 3a. São Paulo, Brazil: Editora Atlas S.A.

Semeoshenkova, V., et al., 2015. Development and application of an integrated beach quality index (BQI). Ocean Coastal Manage.

Van der Sluijs, J.P., et al., 2003. Towards A Synthesis Of Qualitative And Quantitative Uncertainty Assessment: Applications Of The Numeral, Unit, Spread, Assessment, Pedigree (Nusap) System, 25(2): 6.

Van der Sluijs, J.P., Wardekker, J.A., 2015. Critical appraisal of assumptions in chains of model calculations used to project local climate impacts for adaptation decision support-the case of baakse beek. Environ. Res. Lett. 10 (4), 45005.

Thieler, E., et al., 2000. The use of mathematical models to predict beach. J. Coastal Res. 16 (161), 48-70.

Todd, D.J., Bowa, K., 2016. Development of beach health index for the Gold Coast, Australia. J. Coastal Res. Special Issue Coconut Creek 75 (75), 710-714. 
Walker, W.E., et al., 2003. Defining uncertainty: a conceptual basis for uncertainty management in model-based decision support. Integr. Assess. 4 (1), 5-17.

Williams, A., Micallef, A., 2009. Beach Management: Principles and Practice. Eds. Allan Williams and Anton Micallef. UK/USA: Earthscan.
Yepes, V., 2005. Sistemas de Gestión de Calidad Y Medio Ambiente Como Soporte de La Gestión Municipal de Las Playas. Equipamiento y servicios municipales 117, 52-62.

Yepes, V., et al., 1999. Gestión Turística de Las Playas: Aplicabilidad de Los Modelos de Calidad. Revista de Obras Públicas 3 (385), 25-34. 